\title{
Dynamics of loan delinquency by SME owners in Uganda
}

\author{
John Busingye \\ Ibanda University \\ P.O.BOX 35 Ibanda, Uganda
}

\begin{abstract}
The study mainly set out to investigate the factors that influence loan delinquency bySME owners in Uganda. SME ownersin Mbarara Municipality, South West Uganda provided conceptual setting of the study. This paper contributes to the body of knowledge by determining the local business context influencing loan delinquency among SME owners. The study fixated on thefactors that influence loan delinquency by SME owners in Uganda with focus on what SACCOs put into consideration in order to categorize an SME as suitable for micro-lending. The study engaged descriptive research design, where 20 questionnaires were administered to SME owners and detailed discussions of the questions conducted with 6 key informants in the SME sector. The study was grounded on David McClelland's Acquired Needs theory and the Rational Choice theory in helping to understand the subject under investigation. The study further adopted Krejcie and Morgan's (1970) sample size determination methodology to select the respondents. Data was analysed using SPSS version 20, thematic and content analysis. The study findings show that majority of the respondents were male with secondary level of education, majority of the SME entities had been in operation for six years and above and their ability to manage loans was boosted by education, skills and experience. While the majority of the SME owners are accessing and utilizing loan services from the SACCOs, more than half of them have ever been in delinquency over their loan contract. The study recommends that the SME owners learn how to plough back their profits into their business, conduct sound business research so as to increase their operational capital and skills in order to expand and grow their projects. The study concluded that the SME industry is a fertile ground for investment for Uganda, SME owners, and SACCOs.
\end{abstract}

Key words: SME owners, loaning and delinquency.

\section{CONCEPTUAL BACKGROUND:}

Small and Medium sized enterprises (SMEs) are the lifeblood of most economies around the world and any government cannot afford to ignore the sector because of their strategic role in economic growth, development and innovation (Aijukwe, Giles (2009). Nevertheless, SME owners from the formal sector are constrained by the high risks and high transaction costs associated with commercial and micro-lending to thesector. Thus SME owners are more likely to be left without new loans during financial crisis. Access and utilization to financial capital can be a critical factor for the success of SMEs. The ultimate component for progress of the SME sector stands out as access to and utilization of financial capital (World Bank 2017). Earlier studies by Beck (2008) concluded that lack of access and effective utilization of financial capital is ahindrance to growth of SMEs than large firms. It is for this reason that the World Bank listed SME financial access to be a fundamental policypriority.

The substantial evidence of the delinquency design of loans to individual firms in developing markets in general and the new EU member countries in particular is still missing Aijukwe, Giles. (2009)It is in this reason that this paper sought to highpoint factors that influence loan deliquency by SMEs, grounded on Ugandan local context. In Uganda, the informal sector has 
seen its share in total employment rise from $10 \%$ in the 1990 s to $70 \%$ in the year 2000 . The SMEs' share in GDP has also recorded significant increase, rising from 9\% in 1970 to 23\% in 2000 (MFPED, 2007). The informal sector is the second largest source of employment after small-scale agriculture (MFPED, 2005). The 2004 national survey of SMEs shows that about $36 \%$ of the total households in the country are engaged in some form of SME activity (MFPED, 2005). The industry is, therefore, an important source of livelihood for a majority of the country's population.

InUganda,theinformalsector'sshareintotalemploymentstoodat82\%in2010(MFPED,2014).

Besides, SMEs require adequate and timely financial resources to continue contributing to the nation's economy.

Studies by Beck (2010) contend thatbanks consider the SME sector as more profitable as they serve it with different lending methodologies. The scholars found minimal variations in the extent to which SMEs are served by banks based on their foundation set up, eg privatecommunity or government owned). Though, they noted significant variations across banks in developing and developed nations. They resolved that a conducive environment is vital than the size of the firm or bank ownership in influencing bank financing for SMEs. This conducive environment will support the flourishing of the SMEs, and reduce the loan delinquency rates, which hurt SACCOSs. It is therefore vital to understand what determines loan delinquency for lenders, borrowers and governments. This study zeroedat establishing factors that influence loan delinquency by the SMEs, bearing in mind their fundamental role in economic development of Ugandan economy.

\section{Problem statement}

SMEs are the main engines of economic growth, prompting wealth creation for their owners and employment opportunities in the country. Yet SMEs entirely faceinsufficient financial capital that is detrimental to their ability to contribute effectively to sustainable development (Wanjohi and Mugure, 2008). SMEs need to access and utilize financial credit to enable them increase production through innovation and technological advancement, but also repay the loans with interest to the SACCOsaccording to the agreed terms and conditions.

Kamau (2014) argue that flexible and friendly loan repayment schedules can significantly reduce transaction costs and loan delinquency. The scholarsconcludethat the duration of loan repayment schedules influences loan delinquency. The fact is that since most SACCOS loans are not backed by collateral and loan insurance policy, borrowers' main motivation for repaying loans was their higher expectation of access to future loans from the same lending institutions if they repaidpromptly. Nevertheless, a recent BOU survey shows that SMEs topped the list of biggest loan defaulters in the year 2016 (MFPED, 2018). Furthermore, study by Kalyango\& Moses, (2013) points that commercial banks and SACCOsin Ugandahave been suffering serial loan defaulters from multi-borrowers. It is on this basis that this study sought to investigate the factors that influence loan delinquency by the SME owners in Uganda.

\section{THEORETICAL PERSPECTIVE AND LITERATURE REVIEW}

This study was grounded on the theoretical and empirical literature on the subject under investigation. It looks at the David McClelland's Acquired Needs theory and the Rational Choice theory in helping to understand the theme of the study. According to David McClelland, (1996) a human being acquires three types of needs at any time. These include; a) Achievement, b) power and c) Affiliation. The need to achieve refers to the desire to accomplish something. It is the urge to excel. Need for power means the desire to dominateand influence others by 
controlling their actions by use of physical objects, whereasthe need for affiliation implies the desire to establish and maintain friendly relationship with others.

The theory generally articulatesthat running a business needs people to manage risks, undertakeindividual bond for their own performance, pay attention to feedback in terms of cost and profits, and find innovative ways to make and provide new services (Yogendrarajah (2013). The rationale is that most SMEs are managed and operated by the owners with a need to achieve growth to meet their objectives. In this aspect, the theory envisages that people with high desire for achievement value particular workconditions and perform well in them, yet those without such desire will perform poorly. In his study, McClelland concluded that most people who achieve steady results do so based on stimulus, and such people regularly set achievable objectives. Achievement-motivated persons set attainable targets that can influence their efforts and ability. This determines result-orientd approach, which is a characteristic of all successful business entrepreneurs. McClelland contends that achievement-motivated people are generally the ones who make things happen and get outcomes.

\section{Unit of analysis and target population}

\section{METHODOLOGY}

The unit of analysis in this study was the examination of factors that influence loan delinquency among SME owners.

On the other hand, the units of observation for this study were SME owners from whom the data was collected using a structured questionnaire and Key informants who provided qualitative data.

The target population or simply,the entire set of units for which the survey data are used to refer: The target population for this study was SMEs owners operating within Mbarara municipality with population of 200

SMEsasshownbytable1.1below.Thestudytook10\%ofthetotalpopulationattaininga sample unit of 20 respondents who own SMEs within Mbarara municipality and 6 key informants. According to Mugenda\&Mugenda, (2003) a sample of $10 \%$ is acceptable and usable for the study. Stratified random sampling for the owners of SMEs was used so as stratify SME owners according to their nature of business (as shown in table 1.1 below: This enabled the researcher to get the right respondents who had the information to deliver the study objective 
Table 1.1: Target Population

\begin{tabular}{|l|c|c|c|}
\hline \multicolumn{1}{|c|}{ Nature of business } & $\begin{array}{c}\text { Target } \\
\text { Population }\end{array}$ & $\begin{array}{c}\text { Percentage } \\
\text { of total }\end{array}$ & Sample size \\
\hline General merchandise (Kyakara) & 76 & 38 & 8 \\
\hline Road side and evening traders & 31 & 15.5 & 3 \\
\hline Hawking and vending (informal) & 26 & 13 & 2 \\
\hline Fashion design and hair dressing & 15 & 7.5 & 1 \\
\hline $\begin{array}{l}\text { Small scale food and non-carbonated } \\
\text { manufacturing and processing industries }\end{array}$ & 3 & 1.5 & 1 \\
\hline Welding, carpentry and joinery & 10 & 5 & 1 \\
\hline Butcheries \& eating places & 12 & 6 & 1 \\
\hline Transport business & 2 & 1 & 1 \\
\hline Agro business & 8 & 4 & 1 \\
\hline Bars and restaurants & 7 & 3.5 & 1 \\
\hline Total & 200 & 100 & 20 \\
\hline
\end{tabular}

Modified Krejcie and Morgan's (1970) sample size determination

\section{Inclusion criteria}

In order to be included in the sample, only rregistered enterprises which were in operation before the year 2012 were included in the study. The respondent had to give informed consent and ought to have participated in SACCO activities during the period of 2012 - 2019. This period was considered to be enough for an entrepreneur to have gained enough experience in dealing with SACCO loans. All the respondents complied with the inclusion criteria especially the informed consent which had to be given and those that did not consent were not forced to participate in the study.

\section{Factors considered by SACCOs inconcedingloansto SME owners}

According to the key informants and respondents, there are various factors consideredby the SACCOs in conceding loans to SMEs. Through detailed discussions, the Key informants noted the following factors:

Financialviability and legality of the business: The Key informants revealeda pre-evaluation of customer's business activity and financial viability is conducted by the conceding SACCO to ascertain the ability of the SME entity or owner to repay the borrowed capital. In this, the conceding SACCOs require to see the documented cash outflows of the business and other assets owned by the SME owner. SACCOs are also expected to fund activities that conform to the laws of the Uganda. For example payment of taxes to URA and operational licence obtained fromlocal a municipal authority which gives a measure of the financial worthiness of theborrower.

Viable businessproposal: The key informants stated that the SME owner is required to present a well-written business proposal that shows implementation plans, risks reduction and management plans for the business to the lending SACCO. This stipulates the activities the SME entity is involved in and how it has structured budget for the financial capital being sought. The activities should have the approximated returns expected as profits and which the SACCO should term as attainable for them to fund the venture. The SME owner is required to provide a well-drawn feasibility study with the expected cash inflows and outflows.

Monitoring and accountabilitymechanisms:The Key informants noted the SME owner should present business documents like cashbooks, receipts and other books of accounts that will give 
the lending SACCO an overview of the business performance and structures established by the SME owner in running thebusiness.

The size of the business: This was stated by the key informants to be among the factors considered when conceding loans. This is to make sure that capital being sought should be utilised optimally by the SME entity being funded. This helps to prevent overstocking, which may result to loan defaulting due to dead stock and other forms of wastage because of the business' failure to utilise the capital pumped intothe business.

The age of the business owner and history of theenterprise: The key informants reported that the SME entity being given a loan should be at least one year or more in operation. This highlights the ability of the business to thrive through the risks and uncertainties experienced in the world today. Key informants pointed out that"The young the business, the higher the likelihood of it collapsing".

Loan management Training and relationship to loandefaulting: The Key informants stated that training is good for the SME owners accessing loans. The training also reduces the likelihood of loan misuse out of ignorance. According Nawai and Shariff (2012) financial literacy facilitates the process of making decisions concerning development of the business entity and even on how to make payments of bills ontime.

The Key informants noted the loan management trainings offered by the SACCOsto the SME owners seeking loans are meant to enable the clients be more resilient in business operations and investment of the loan capital received or expected to be received. The training components mentioned by SME owners and Key informants includerisk management, business plan development, business evaluation, business documentation, stock taking and savings plan orloan schedule.

\section{Factors influencing loaned linquency}

The study sought to know whether Gender of SME owner influenced loan repayment.The study found out that women are likely to default loans than men. One key informant had this to say out of the 5 total defaulters on my desk, only two are men. My findings contradicts to the findings of Mokhtar(2011), which found out that loan repayment problem was higher for males than for females, but it confirms Seyed, Majid, Nurulizwa, Mohd\&Hamid (2013)and Krithie(2015 who also found that women were more likely to default on loan repayments thanmen.This default by women was associated with family responsibilities, family crisis and sickness of a family member. It comes out clearly from the key informants and the SME owners' responses that various reasons can lead to defaulting loans. These may include:

Lack of proper and detailed market research before one ventures in the business. As testified by key informants, such a situation will summit in poor business plans development and poor profit estimates, which makes the businessperson not to develop devices of dealing with risks and uncertainties in the business site.

The character of the SME owner was reported by key informants to be the credible cause of loan defaulting, for example, where the SME owner is not consistent on a specific business line but he keeps jumping from one market sector to another without specializing in one line of business.This puts the business at a risk.

The Key informants and SME owners identified loan diversion as the most likely cause of loan defaulting by the SME owners, for when one diverts the funds from the business and invests 
somewhere else. This affects the profit and cash flows of the business plan a $s$ activities, resulting into loan delinquency.

Poor business plans was also identified by some key informants and SME owners as the major cause of poor success of business ventures and loan delinquency. They reported that when plans are poorly drawn, it affects business implementation, measurement and evaluation resulting to falsified expectations, thus influencing business performance and causing loan delinquency.

It was highlighted by the key informants that failure to plough back the profits gained from a funded venture risks loan delinquency. When profits arenot ploughed back into the business, such a situation leads to the collapse of the entity with the SME owner going into losses and defaulting on his or her loan contracts.

Stiff market competition and production cost factors were mentioned by the key informants. They stated that in order for SME owners to compete successfully, their cost of production must be low. Without this, stiff competition may mean minimal profit margins and inability to meet other business obligatory and statutory contracts like remittance of government taxes. Some SME owners hire means of production. If the hiring cost of production is high, it will affect the borrowing SME owner by spending more on this and disregard the loanrepayment.

According to some key informants, level of education shows the level of logicalexamination an individual can make. People with high level of education are thought to make informed business decisions such that when a business owner is obtaining a loan for the SME unit he or she knows that the unit is in a position to repay the loan with interest and have some excess to reinvest back into the industry. This helps the business owner to avoid defaulting on his repayment. This is confirmed by Aijukwe, Giles(2009) who states that all businesses all over the world should keep records of their transactions to facilitate decision making such as payment of bills on time, which improves the credit worthiness of the SME entity. The key informants stated that an SME unit and owner are entwined and intimate. The owner runs the unit with his mind, skills and understanding; the SME owner with higher level of education is exposed to ideas and up to date views, thus having wider and sound businessphilosophies than one with low or no education. In principle, the one with higher education will organise his loaned money well and invest in what is thought to be profitable thus enabling the borrower to repay his/her loan on time.This can further be explicated by David McClelland's acquired needs theory, which generally argues that running a business requires people to moderate risks, assume personal responsibility for their own performance, pay close attention to feedback in terms of cost and profits and find new or innovative ways to make new products and provide a new service Nawai and Shariff (2012). The implication is that most of the growing SMEs are managed and operated by owners who have a need to achieve and grow. Yet, the theory envisages that people with high need for achievements value particular worktask circumstances and achieve better in them, however their counterparts will achieve less.

\section{Loan repayment time interval by SME owners}

The study also sought to establish the time interval within which SME owners paid loans. A majority paid monthly schedules, others paid weekly while none indicated daily loan repayment. This confirms the findings by Harris, (2006), Armendariz and Morduch, (2007) and Jain and Mansuri, (2003), which stated that among the SACCO clients who are willing to borrow at either weekly or monthly repayment intervals, a more flexible schedule can significantly lower transaction costs without increasing client default. The SMEs using monthly repayment intervals are in a healthiersituation to monitor and reduce their loans 
consistently thus enabling them to reconcile their payments with a lot of ease as emphasized by SME owners and key informants. It was also reported that monthly repayments lower the transaction costs like deposit charges, transport to and from the SACCO premises compared to weekly schedules. This allows savings and increased profit margins as well as growth of thebusiness hence reduction in loan delinquency.

\section{CONCLUSION}

The SME sector is a fertile ground rich for investment for governments, and NGOs,SME owners, SACCOs and other micro-banking institutions. This sector is the only one in which men and women can breedeconomic prosperity. Though the industry has some uncertainties and threats, sound risk management plans and methodologiescan fruitageconstructiveupshots that can mend the living standards of the SMEs owners, profit margins for the SACCO industry and elevate global national economy of any country.

\section{RECOMMENDATIONS}

The government should invest inSME by extending low interest loan funds through SACCOs so as to solve community problems.This however, requires the efforts of all stakeholders involved, including the customers and the SME owners-being the drivers of the industry. Skills on enterprise development and risk management to enable them avert the risks involved in the business domain. Once this is executed by government the SMEs are likely to shine and recordconstructivedevelopment practices. The SME industry is here to stay as long as there are development practitioners rethinking and articulating their business ideaslogically.

\section{References}

Aijukwe, Giles. 2009. "How to Use a Loan to Grow Your Business.” Monitor Publications Limited Thursday 17, September 2009.

Armendariz, A. and Murdoch, C. (2007).The Economics of Micro Finance. Cambridge: MIT Press.

Ayyagari M., Beck,T. and A. Demirgüç-Kunt. (2007). Small and Medium Enterprises across the Globe.Small Business Economics 29, 415-434.

Beck, T. D.K. (2008).Bank Financing for SMEs around the World: Drivers, Obstacles, Business Models, and Lending Practices.World Bank Policy Research Working Paper 4785.The World Bank, Washington DC.

Beck, T. K. (2010).Bank Financing for SMEs: Evidence across countries and banks ownership Types. Journal of Financial Services Research 39,35-54.

David McClelland, (1996) .Achievements in Motivation Theory. London: Sage Publishers: Sage Publishers.

Harris, (2006).Empowering women with Micro-credit.Micro-credit summit Compaign. Longman Publishers the Univiversity of Michigan .

Jain S. A and Mansuri, (2003), A little at a time: the use of regularly scheduled repayments inmicrofinance programs. Journal of Development Economics, 72 (1), 253-279. Kenya Ministry of Finance \& Planning (2000).Annual report

Kalyango\& Moses, (2013) "Uganda"s Experience with Tiered Banking Regulation". Bank of Uganda.

Kamau P. W (2014). Gender Relations in Access, Control and Utilisation of Microcredit Resources: ACase of Women in Kiharu Constituency Kenya. Kenyatta University

KiraitheP(2015) Factors that Influence loan defaulting by SME owners in Kenya: A study Of SME within Thika township of Kiambu county.

Krejcie, R.V. and Morgan, D.W. (1970).Determining Sample Size for Research Activities.In Hill, R. (1998). "What Sample Size is 'Enough' in Internet Survey Research"? Interpersonal Computing and Technology: An electronic Journal for the $21^{\text {st }}$ Century. http://www.emoderators.com/ipct-j/1998/n3-4/hill.hmtl Accessed on 20/12/2017:

Ministry of Finance Planning and Economic Development (2005).Measuring poverty.Poverty Monitoring and Analysis project. 
Ministry of Finance Planning and Economic Development. (2014). Uganda National Household Survey 2012/2013. Social Economic Survey, UBOS Entebbe.

Ministry of Finance Planning and Economic Development.(2018). Uganda National Household Survey 2016/2017. Social Economic Survey, UBOS Entebbe.

Mokhtar, S. H. (2011). Micro-credit Performance in Malaysia.Lincoln University, New Zealand.

Mugenda, O. \&. (2003). Research Methods: Quantitative and QualitativeApproaches. Nairobi: Acts Press.

Nawai, N., \&Shariff, M. N. M. (2012).Factors affecting repayment performance in microcredit programs in Malaysia. Procedia - Social and Behavioral Sciences, 62(24), 806.

Seyed, Majid, Nurulizwa, Mohd\&Hamid (2013).The role of microcredit on the wellbeing of poor people. Case studies from Malayasia and Yemen. Accessed 23rd December, 2017 on URL: http://dx.doi.org/10.5539/ass.v10n1p230

Wanjohi, A.M. and Mugure, A. (2008).Factors affecting the growth of MSEs in rural areas of Kenya: A case of ICT firms in Kiserian Township, Kajiado District of Kenya.

World Bank. (2007). Global monitoring report: Confronting the challenges of gender equality and fragile states. Washington, DC: The World Bank.

World Bank 2017).Review of Small business activities. Washington D.C.: World Bank.

Yogendrarajah, R. (2013). Challenges faced by women in accessing credit from Microcredit Institutions in Srilanka. The international journal of Economics and business management. East Publications 